\title{
Legal Analysis on Exchange of Right to Contract for the Rural Lands' Management
}

\author{
Yang Yang \\ Southwest University, Chongqing, China \\ Email: yangkent78@qq.com
}

Received 5 October 2015; accepted 26 December 2015; published 29 December 2015

Copyright (C) 2015 by author and Scientific Research Publishing Inc.

This work is licensed under the Creative Commons Attribution International License (CC BY). http://creativecommons.org/licenses/by/4.0/

cc) (i) Open Access

\begin{abstract}
Although the existing laws have carried on the detailed provisions to the right to contract for the lands' management, all parties' interests conflicts were caused by the farmer's little enthusiasm and excessive interference for the exchange's behavior and the exchange was thus blocked. The situation did not apparently tally with the integration system's goal for perfecting the urban-rural development that was proposed in the $18^{\text {th }}$ CPC National Congress. To perfect the approval right, the restrictive provision shall become the key to standardize the exchange market, give more vitality to the right to contract for the lands' management and solve the current problems.
\end{abstract}

\section{Keywords}

The Right to Contract for the Rural Lands' Management, Exchange, The Approval Right, The Restrictive Provision

\section{Introduction}

It's clearly put forward in the Decision of the Central Committee of the Communist Party of China on Some Major Issues Concerning Comprehensively Deepening the Reform “中共中央关于全面深化改革若干重大问 题的决定” in November 2013 that accelerating the building of a new type of agricultural operation system, endowing farmers with more property rights and improving mechanisms and institutions for integrated development of urban and rural areas are the target of government's following work. It is the foundation to achieve all the goals of reform for upholding and improving the system of rights to contract the rural lands' management. And it is an important way to solve the issues concerning agriculture, countryside and farmers and to realize the farmers' rights for endowing farmers with the exchange rights to contract the lands' management. With the implement of Law of the PRC “物权法” on Land Contract in Rural Areas and Real Rights Law of the PROC “农村 土地承包法” in the recent years, the exchange order of right to contract the lands' management has been syste- 
matically standardized, but there are still a number of problems which are not only solved, but directly affect all parties' interests to lead that the exchange is blocked. Therefore, it is necessary to thorough study in these problems and current situation.

\section{Its Current Situation}

\subsection{Its Great Demand}

It is the legacy of the period of planned economy to restrict the factors of production flowing, while market economy requires all the factors of production to flow as free as possible. In the context of reforming to build the socialist economy market and develop a modernized agriculture, it's a corollary that the management rights of contracted rural lands, also the fructose of lands, as a factor of production, should be confirmed and guaranteed. Once the transfer doesn't work out well, the value of the lands cannot be showed, and also it's not helping to improve the disposition of social resource.

The original intention of the management rights of contracted rural lands, adopting the pattern of equal farming, is to guarantee farmers' basic living standard and to stimulate their enthusiasm for production. At that time of special social background, however, the act of transferring was unnecessary when this system actually met the needs of improving productive efficiency to some degree. But with the development of the market economy, the pattern of small family household and equally contracting the land has resulted in the lands being divided into many small pieces. Especially when scale management has already become an important measure of the development of modernized agriculture, simply emphasizing equality but neglecting efficiency just can’t adapt to the overall economic development situation.

Focusing on the demand of development in rural areas, there are not only a large population but also many complicated problems involved. To break the dilemma, the productive forces must be further liberated and urbanization therefore becomes the only approach to solving the problems in rural areas. On the one hand, the city absorbs the rural population as workers, fully stimulating the human element in market economy. On the other hand, through working people of rural areas get their earned income during the urbanization process, compensating and thus stabilizing the rural areas. Nevertheless, among the rural surplus population are mostly left-behind elderly and children who either do some simple farming or just leave the lands uncultivated, resulting in a low rate of land utilization. All these factors have provided the possibility for transferring management rights of contracted rural lands.

\subsection{Its Small Proportion}

According to the report of the rural areas' transferring situation of Sichuan in 2007, the land transferred amount accounts for $9.1 \%$, the proportion in Zhejiang is $23.47 \%$, and the proportion in Haiyan county of Zhejiang is $3.22 \%$, however, the land transferred proportion in Henan accounts for only $2.58 \%$ in 2005, and the proportion in Hubei is 5\% in 2005 ( $\mathrm{Lv}, 2010)$. It's easy to see, through the data given above, that a significant feature of current transferring market is that the proportion of land transferred is generally small. Admittedly it is connected with the local economic development, even in the well-developed areas the transferring proportion is still far from the reach of the standard of scale management.

\subsection{Its Forms' Polarization}

It prescribes in the Law of the PROC on Land Contract in Rural Areas “农村土地承包法” a limit to the exchanging form which includes subcontracting, transferring, interchanging, renting, pledging and buying a share. Nevertheless looking from the data collected, the main form of transferring is subcontracting. It's no hard to see, through analysis of current situation, that most of the subcontracting is spontaneous behaviors. In fact, rural areas nowadays are still accustomed to a social pattern of acquaintance. And a spontaneous form of transfer, subcontracting, which needs mutual-trust as the foundation of transaction, is perfect for acquaintance transaction. A spontaneous behavior like this is on the one hand short-term and occasional, with usually gratuitous transactions on both sides and a lack of exchanging contract during the transaction; on the other hand it shows that the spontaneous subcontracting mainly happens on farmers from the same collective organization, that is, the qualification of the transaction subjects is obviously exclusive. Besides subcontracting, industrial management of agriculture projects driving the exchange right to contract the rural lands' management becomes another impor- 
tant channel. This new kind of transferring form is mainly led by major agricultural companies. The farmers let out their management right of the lands and become the shareholders of the company that gains profit by marketing high value-added agricultural products; and farmers either get their rentals and dividends through transferring the right, or earn their income by working in the company or selling agricultural products.

\section{The Analysis for Its Current Situation}

\subsection{The Farmers' Little Enthusiastic about Its Exchanging}

On the one hand, the land has always been treasured so much by the farmers of China because it ensures their essential living. Subconsciously losing the land means losing everything to them. Moreover, for a long time the mode of household contracting management has been in accord with the farmers' values; generally they accept the idea of equally dividing the land and regarding it as part of their traditional property. Furthermore, at present the agricultural policy of China supports farming by exempting agricultural tax, which too will motivate the farmers to keep the land themselves to produce, making the management rights "less profitable" and "more guaranteed”. On the other hand, most of the interested parties participating into the transferring are farmers who substitute verbal agreement for necessary transfer contracts based on the mutual-trust between acquaintances, thus resulting in a growing number of transferring disputes; during the process of transaction, an overly strict procedure of transfer has made the farmers lose a number of potential assigners, increasing the difficulty of transferring lands and thus making the farmers less positive (Tao, 2011).

\subsection{The Collective Economic Organizations' Excessive Interference}

It is stipulated in the sixth article of the Constitution of the PROC “宪法” that the basis of the socialist economic system is socialist public ownership of the means of production, namely, ownership by the whole people and collective ownership by the working people. Collective organizations such as township governments and village committees are the very reflection of the public ownership in our country. In fact, the land itself is owned by the country rather than the farmer; and the collective economic organizations exercise the ownership on behalf of the country, playing a role as the party awarding the contract, owner and supervisor of the exchanging procedure. Such position has granted the collective economic organizations an enormous public power. For example, during the transfer between the major agricultural companies and the farmers, not only does the collective economic organization play the role of linkage but it also negotiates with the companies on behalf of the interest of the farmers, maximizing the benefits through collective strength. But at the same time the collective economic organizations considering their own political achievements will sometimes reach agreements that are against the farmers' will with the companies and compulsively transfer the management rights of the contracted rural lands. Even when the companies gain high profits, it's impossible for the farmers to gain extra income. The collective economic organization's right of agreement endowed by the law is a typical kind of public power. The intention of this regulation is to give directions to the farmers during transfer considering that most of them are uneducated; in addition, collective economic organizations supervise the interested parties and transferring bid to prevent the land from being farm-oriented. In practice, however, some of the governors of the organization will seize the opportunity to interfere in normal transferring activities using their right of agreement or interfere in normal transferring procedure with their negative right to take revenge on the farmers.

\section{The Legal Reflection on the Current Situation}

\subsection{To Perfect the Approval Right}

China is a populous country and it has always considered grain issue to be an aspect of national economic security. The reason behind it is that the land has for a long time provided a lasting and countable essential living security for the farmers as their basic means of production and it is at the same time the basic guarantee of the stability of the social order. Therefore, protecting the farmland means not only ensuring that farmers get the land, but also prohibiting extensive use of the land such as illegal occupation and blind development of the farmland. The public interest attribute that farmland resources possess determines that collective economy of the public-owned economy also possesses the attribute of social interest (Wang, 2011). A collective economic organization should therefore preserve the interests of the majority of the society-the security of the farmland. Nevertheless, with the development of economy, it's an inevitable tendency for the farmland to be utilized intensively 
and on large scale. Meanwhile, farmers still need to transfer the lands to manifest their right. The contradiction between protecting the farmland and the right of farmers has become a trade-off that the current collective economic organizations have to confront. As a matter of fact, the collective economic organizations are endowed with the public power that guarantees public and social interests by the essential request of public ownership and developing demand of agricultural economy. After all, when faced up with efficiency principle and equity principle, market economy will forwardly choose to give priority in efficiency and it is public power that realizes the principle of equity.

Law of the PROC on Land Contract in Rural Areas “农村土地承包法” regulates in article 37 that it should be consented by the part awarding the contract to circulate in the form of transfer; and this is a clear proof of collective economic organizations choosing to protect collective interests when faced up with private and public interests. The right of agreement owned by the part awarding the contract is exactly the concrete manifestation of public power. But the problem is, from the perspective of law enforcement attitude, the part awarding the contracts' attitude towards transfer is absolute dominant. Once the part awarding the contract exercises the negative right over the farmers' transferring activity, it is considered to be invalid, moreover, it should mentioned in the regulation according to the word, it means that the transfer contract too is invalid. Obviously, the agreement of the part awarding the contract lacks reference standards and essential basis while executing it. In such case, should the right of agreement be eliminated from the public power that the part awarding the contracts have? The right of agreement not only represents the country and the community's attitude towards farmers. I believe, but it also supervises the transferring behaviour, and eliminating it will be damage to farmland protection. Therewith, we can regulate in law the situations where the part awarding the contracts cannot agree and the basic principles of consenting to transferring. Through this, we can urge the interested parties to observe the transfer regulation and raise there awareness to protect the farmlands. Also, the artificial obstacles during the transferring procedure can be lessened.

\subsection{To Improve the Restrictive Provisions}

It is regulated in the 23th article of the Law of the PROC on Land Contract in Rural Areas “农村土地承包 法”that the exchange right to contract the lands' management should abide by the following two principles. The first is that the ownership nature of the lands and its agricultural purposes will not be changed and the second is that the acquiring party should acquire the ability of agricultural management. Therefore, in this way, the law protects the farmlands by regulating the ability of the transfers and the purpose of the farmlands. Admittedly such regulation demonstrates that the legislators at that time took full account of the limited capacity of the land and the farmers' essential living demand of the lands. But in practice, the two of these are both principle provisions that are less practical and need further discussion.

To begin with, the purpose of the acquiring parts should acquire the ability of agriculture managing is to prevent the managers who are incapable or have no intention of farming from using the benefit of land transferring to inflate the price of the lands. Even though the regulation demonstrates absolute equity and justice, there are still some questions in need to be figured out. Firstly, what is the criterion for "the ability of agriculture managing"? There is no specific regulation about it in our law. Practically speaking, most of the skilled managers are the individual farmers who do the farming themselves. But in order to develop scale management, it's impossible to force the managers to know how to farm. The development of market economy eventually brings cooperation. Even if the person does not have the farming and producing facilities required and is inexperienced in farming can manage and cultivate the lands by employing and entrusting other people. Secondly, does the regulation that acquiring part should acquire the ability of agriculture managing necessarily result in farmland protection? In fact, those who acquire the ability of agricultural management might gain profit by transferring again instead of working hard at farming, conversely, the acquiring parts that are incapable of managing can realize agricultural managing through investment and agency. Thirdly, does the transfer contract signed by the farmer and the acquiring part that doesn't have the ability of managing still have legal validity? Still, there is no specific statement in the law. But according to the word should in the regulation it can be presumed that the act and the contract are all ineffective (Li, 2010). It's not difficult to conclude from the three points discussed above, that the regulation of forcing the acquiring parts to acquire agriculture managing ability is indeed redundant. Just as the assessment of the ability of agriculture managing in the Agriculture Law of Japan focuses on whether leasing and farming the land for a long term and whether possessing the qualifications to lease the land, the 
evaluation towards acquiring parts should be broader. Accordingly, under the background of promoting to endow farmers more property rights, farmers cannot sacrifice self-interests just because they are unable to assess the agriculture managing ability of the acquiring parts. In order to protect the farmland resources we only need to regulate that the agricultural purpose of the farmland mustn't changed.

Secondly, the agricultural purpose of the farmland mustn't changed is an expression of the legislators' attitude to consider equity when private rights conflict with public interests, and also a demonstration of protecting agricultural production and making full use of the farmlands. From a literal sense, agricultural use actually means agricultural purpose; but how should we understand agricultural purpose? The act of cultivating is obviously on agricultural purpose, but what about the act of agricultural machining and services? I think it involves the problem of the integration of China's actual situation and the agricultural purpose. Take some of the developed countries for example, the agricultural purpose of the acquiring parts should only be agricultural machining and services and direct agricultural production is not allowed. Such regulation aims to maintain the farmers' enthusiasm and prevent the acquiring parts from getting the lands by transferring and then occupying farmers' interests. But in our country, proceeding from the agricultural laws' imperfection and lacking specific standards, some of the farmers need to get essential living materials through cultivating; others find jobs in the city and leaving the elderly and the children either setting aside the land or continuing inefficient farming; on the other side, some individual farmers and major agricultural companies need farmlands for scale production while some acquiring parts attempt to gain profit by transferring the land again. Therefore, I think that based on China's actual situation, we should make specific explanation on "not changing the agricultural purpose", that is, by principle acquiring parts should only be allowed to engage in direct agricultural production like planting and cultivating in order to protect the farmlands from changing the basic use of the farmlands.

\section{Conclusion}

In a word, the problem for exchanging right to contract the rural lands' management is the interests' conflict between the public authority and the farmers' rights. The two parties' relationship must be taken into full consideration in the law regulations, and it should be avoided to lose the driving force of land exchanging because of the excessive correction when the efficiency principle is given full consideration in the pursuit of the balance principle.

\section{References}

Li, P. (2010). Thought of the Legal Issues for the Exchange of Right to Contract the Rural Lands' Management. Shanghai: East China University of Political Science and Law.

Lv, S. C., \& Ding, Q. (2010). The Investigation and Reflection to the Problem of the Rural Land Exchanging. Journal of Theoretical Exploration, 2, 75-76.

Tao, J. K. (2011). Analysis of the Problem to the Rural Land's Exchange. Journal of Economic Review, 10, 45-50.

Wang, Y. N. (2011). Research the Legal Environment on the Exchange of Right to Contract the Rural Land's Management. Journal of Legal System and Society, 15, 217-218. 